Portland State University

PDXScholar

\title{
The image of the Habsburg Empire in Joseph Roth's Radetzkymarsch and Die Kapuzinergruft
}

Deborah O'Dell

Portland State University

Follow this and additional works at: https://pdxscholar.library.pdx.edu/open_access_etds

Part of the German Literature Commons

Let us know how access to this document benefits you.

\section{Recommended Citation}

O'Dell, Deborah, "The image of the Habsburg Empire in Joseph Roth's Radetzkymarsch and Die Kapuzinergruft" (1967). Dissertations and Theses. Paper 3744.

https://doi.org/10.15760/etd.5628

This Thesis is brought to you for free and open access. It has been accepted for inclusion in Dissertations and Theses by an authorized administrator of PDXScholar. Please contact us if we can make this document more accessible: pdxscholar@pdx.edu. 
AN ABSTRACT OF THE THESIS OF Deborah O'Dell for the Master of Arts in German presented July 23, 1987.

Title: The Image of the Habsburg Empire in Joseph Roth's Radetzkymarsch and Die Kopuzinergruft.

APPROVED BY MEMBERS OF THE THESIS COMMITTEE:

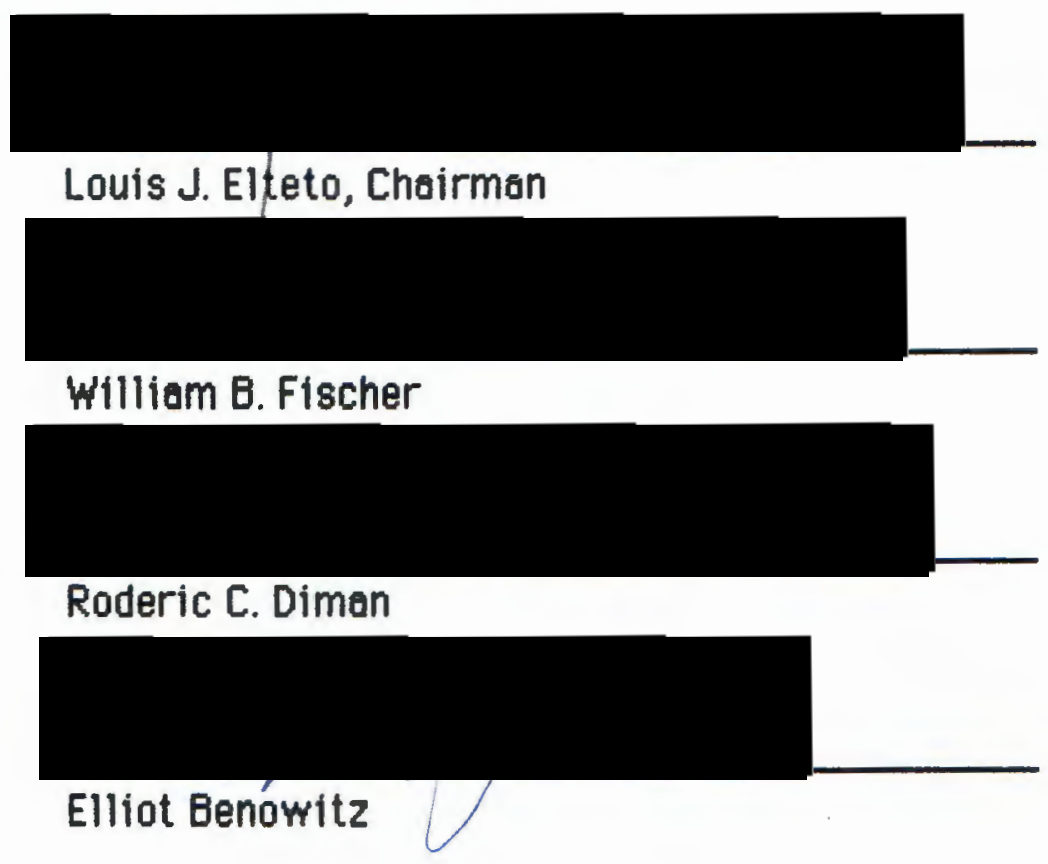

This thesis explores Joseph Roth's image of the Habsburg Empire as depicted in two of his works, namely Radetzkymarsch (1932) and Die Kapuzinergruft (1938).

Joseph Roth is perhaps the chronicler par excellence of the Habsburg Empire. Among the authors who have attempted, through their works, to come to grips with fin de siècle Austria, he has remained 
relatively unknown. However, Roth was keenly aware of the Monarchy's ultimate decline and fall. Losing the Monorchy was his most intense experience and his personal involvement with the Empire plays a dominant role in these novels. Hence, Chapter I provides a biographical sketch.

Chapter II examines Radetzkymarsch, his most significant novel. The novel gives an account of the nihilistic despair and insecurity that took hold of the people during the foll of the Monarchy. It is a realistic story of three generations of a Slovenion family, whose fate symbolically coincides with that of the Monarchy. After a brief plat summary, the chapter provides an analysis of the fictional characters and leitmotifs.

Chopter III investigates Die Kapuzinergruft, the parallel and anochronistic sequel to Rodetzkymarsch. The novel tells of the some decoying world as Rodetzkymersch ond also mirrors the fate of Austrio in its characters. The chopter is similer in structure to chapter II and focuses on the espects of the novel that illuminate Austrian society during and ofter the fall.

The concluding chapter gives a brief overview of the major similarities and dissimilertties and argues that Roth's image of the Empire did nat change. Die Kapuzinergruft is seen as the logical continuation of Radetzkymarsch, and its worthy conclusion. The emptiness and suffering Joseph Roth struggled with throughout his life seem to have been the major impetus behind his creativity. He recognized the disease which infected the society of his time and clearly conveys his understanding on the pages of these two novels. 
THE IMAGE OF THE HABSBURG EMPIRE IN JOSEPH ROTH'S

RADETZKYMARSCH AND DIE KAPUZINERGRUFT.

\author{
by \\ DEBORAH O'DELL
}

A thesis submitted in portiol fulfillment of the requirements for the degree of

MASTER OF ARTS

in

GERMAN

Portlend Stote University

1987 
TO THE OFFICE OF GRADUATE STUDIES AND RESEARCH:

The members of the Committee epprove the thesis of Deborah 0'Dell presented July 23, 1987.

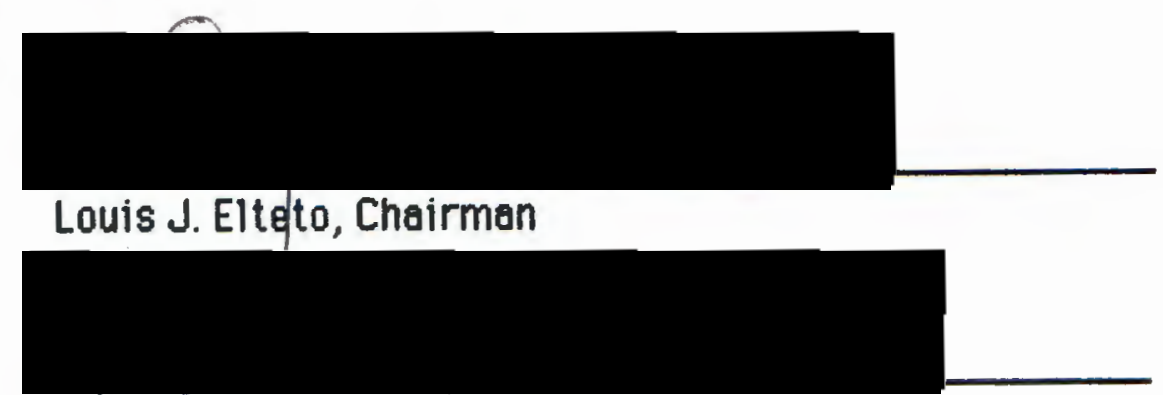

Williom B. Fischer

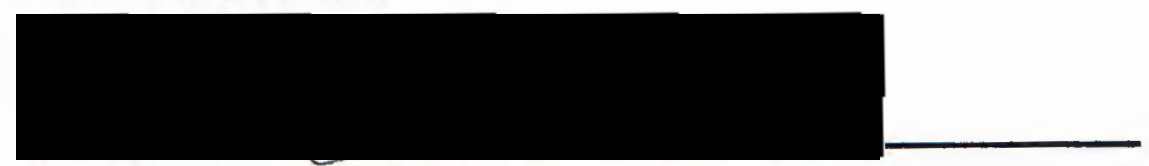

Roderic C. Diman

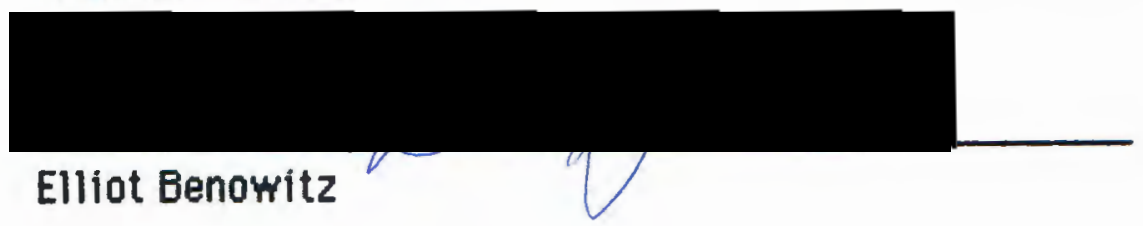

APPROVED:

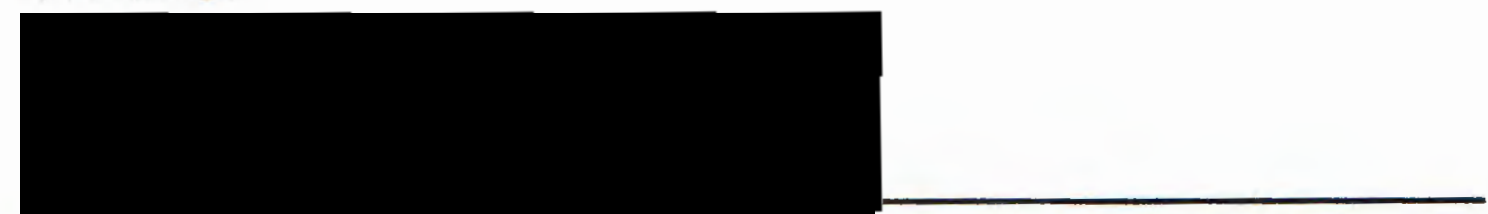

Roderic C. Diman, Head, Department of Foreign Languages and Literatures

Bernard Ross, Vice-Provost for Graduate Studies 


\section{TABLE OF CONTENTS}

CHAPTER

PAGE

1 INTRODUCTION............................... 1

II A BIOGRAPHICAL SKETCH ..................... 3

III RADETZKYMARSCH......................... 15

IV DIE KAPUZINERGRUFT $\ldots \ldots \ldots \ldots \ldots \ldots \ldots \ldots \ldots, 33$

$\checkmark$ CONCLUSION $\ldots \ldots \ldots \ldots \ldots \ldots \ldots \ldots \ldots \ldots, 44$

A SELECTED BIBLIOGRPAHY $\ldots \ldots \ldots \ldots \ldots \ldots \ldots \ldots \ldots, \mathbf{5 0}$ 


\section{CHAPTER I}

\section{INTRODUCTION}

The deterioration of the Habsburg Empire, the First World War and its aftermoth offered numerous Austrion writers of the time a topic for literery creativity. The interest and the importance of the Austrian situation during the first four decedes of the twentieth century lie in the fact thot political conflicts and sociol tensions were acute. Many outhors tried to come to terms with the repid and yest changes through the medium of literature. One such author was Joseph Roth (1894-1939).

As an suthor and a journalist, Roth criticized and chronicled the fall of the Austro-Hungerien Empire and the rise of Nazi power in the Austrian Republic. His tragic life and conflicting loyalties intensified his imege of the Habsburg Monerchy. Although most of Roth's work revolves around the decline and foll of the Empire, this thesis will concentrote on Roth's picture of the Empire in only two of his novels, namely Radetzkymarsch (1932) and Die Kopuzinergruft (1938).

In these novels Roth coptured the loss of direction, alienation and foding of social and moral yolues over a spon of seventy-nine years, 18591938. The cheracters represent and illuminete the Austrien society of Roth's lifetime. Their fates symbolically coincide with that of the Monerchy, and are undoubtedly bound to Roth's own fate, as he saw it. He had lost his fatherland and nothing could fill the void he felt. 
Roth's major concern in Radejzkymersch and Die Kopuzinergruft was not to show the decay of political and economic structures, but rather to draw an emotional and vivid portrait of the decay of life: the individual's loss of power and identity. By anolyzing and compering the characters of these novels I will show that Roth comprehended the society of pre- and post-war Austrio.

A further concern of this work involves the reputation of Die Kepuzinergruft. I hope to show that the novel deserves the same recognition as Radetzkymarsch, and should be reexamined by those who see it as historical escapism. After careful examination and evaluation of the material I hope to present to the reoder a strong orguement that demonstrates the equal value of both novels.

Radetzkymorsch sets the stoge for Die Kapuzinergruft, and also introduces the reoder to the milieu of turn-of-the-century Austria and the ensuing years. Roth's aworeness of the catastrophe of the late 1930's is mode clear in Die Kepuzinergruft. Any belief he moy heve conveyed in Redetzkymarsch for the restoration of the Empire's past glary and power is destroyed. Nonetheless, I feel Roth was able to continue his realistic and detailed picture of the social and inner decadence of the Austrian Empire ond Republic. Although the Empire hed died, the llls of society continued in the eyes of Joseph.Roth. 


\section{CHAPTER II}

\section{A BIOGRAPHICAL SKETCH}

Der Mensch kenn seine Jugendeindrūcke nicht los werden, und dieses geht so weit, doß selbst mangelhafte Dinge, woran er sich in solchen Johren gewöhnt und in deren Umgebung er jene glückliche Zeit gelebt hot, $1 \mathrm{hm}$ ouch spater in dem Grode lieb und wert bleiben, doB er daruber wie verblendet ist und er des Fehlerhofte doron nicht einsieht.'

This quote obout humen noture, token from Johonn Eckermonn's Gesproche mit Goethe, is undoubtedly opplicoble to Joseph Roth's life. Born on September 2, 1894 in Brody, Galicia, the easternmost province of the Austro-Hungerien Monorchy, Roth witnessed from chllahood the decey of the once great Empire. He lived his youth in the final steges of the history of the Empire ond the impressions formed in him in this time were destined to become the centrol theme oround which his later works revolyed.

Dovid Bronsen, Roth's chief biogropher, has dubbed Roth o mythomeniec. The purpose of the following biogrophical sketch is to seperote myth from reality and to point out some focts thot were significant in shoping Roth's cheracter and eventually his work.

The adult Joseph Roth often mythified, in the sense of consciously not giving true information, meny focts of his post. The first myth concerns his place of birth, Brody, in Eostern Golicio. Brody, ten kilometers from the

1 Johonn Peter Eckermonn, Gesoröche mit Goethe in den letzten Jahren (Berlin, W. Ger:: Aufbau Verlog, 1956): 499. 
Russian border, was inhabited largely by Jews. "No other town in the "crown land" had such a high percentage of Jews."2 From 1901-1905 Roth went to the Jewish Beron Hirsch elementery school where he studied Hebrew and Germen. Bronsen writes, "Aus der Schule und seiner frühesten Jugend stammen auch die Ansätze zu Roths komplizierte Beziehung zu den Juden."3 Although Brody was the source of Roth's Jewish identity, he became defensive and so uncomfortable about his Jewishness that he fabricated a non-existent birthplace, which he called alternately "Schwabendorf" or "Schwaby". "Roth avoided Brody once he left it and arosed its name from his vocabulary except when he conversed with Jews from that locale." 4

From 1905-1913 Roth visited the K K Kronprinz Gymnasium, the only one of its kind in Galicio. And here ogain he was a lone wolf with a limited number of acquaintances. The Gymnasium was not strictly Jewish, but the mojority of students that were Jewish attended it. Attendance to the synogogue on Sabbath was mandatory for Roth. It was during this time that he familierized himself with the orthodox Jewish customs which he later wrote obout in Hioh and Juden ouf Wonderschoft. For Roth, the next myth developed during these years, and concerns a scholarship.

Living in the house of his uncle with his mother and grandfother, Roth grew up in poor, but not unbearable conditions. The tuition charge of fifteen Gulden a semester was quite a financial burden for the Roth family: they

2 Dovid Bronsen, "The Jew in Search of a Fotherland: The Relotionship of Joseph Roth to the Habsburg Monarchy," Germenic Review 54.2 (1979): 54.

3 Dovid Bronsen, Joseph Roth: Eine Biographie, (Kőln, W. Ger.: Klepenheuer, 1975): 65.

4 Bronsen, The Jew in Search of a Fatherland," 55. 
could live on that amount for a month. Although the government awarded scholarships to needy students, Roth never received one. "Roths Behauptung, er sei Stipendiat gewesen, ... gehört vermutlich dem Reich seiner Legenden on. 5

Roth wos an outstanding student ot the Gymnasium in Brody. Although he wos o shy outsider, he seemed to come out of himself during German class. "[Er] legte als Schüler Wert ouf gute Zensuren, do sein Ehrgeiz nach Anerkennung durstete. 6 It is during this time that his love for books, especially poetry, developed. Under the influence of Mox Londau, his German literature teacher, Roth became aware of his poetic talent. The relationship between the two was of utmost importance for Roth's intellectual and literary development. "In Max Londau ... f fand der sensible Gymnasiost einen Freund und Förderer, der inm gern seine Berufung zum Dichter bescheinigte."7 The following poem written ot the oge of eighteen to his uncle willi Grubel is a prime example of his ability to compose, and at the same time discloses Roth's real and imaginary worlds.

Oft spinn' ich alte schöne Marchentroume Und glaub' an Wunder, wie ein Kleines Kind --

Do fegt der rouhe Sturm durch all Babume, Es heult und pfeift durch alle Lebensröume Der Wohrheit Lled der rouhe Herbteswind.

Und ich erwache aus den Träumereien, Der kalte Hauch des Lebens mich umzieht --

5 Bronsen, Eine Biographie, 80.

6 David Bronsen, "Die Ambitionen des jungen Joseph Roth," Text und Kritik Sonderband (1974): 38.

7 Bronsen, Eine Blographie, 85. 
Dahin sind alle Elfen und die feien, --

Im Kample will ich mir die Brust erneuern, und sturmgestählt sing' ich das Schlachtenlied. 8

More compliceted than the foregoing myths was Roth's constant preoccupation with the father he never had. His father, Nachum Roth, a grain buyer for an export business in Hamburg, and his mother, Mario Grübel, both of Jewish heritage, were married in 1892. However in 1893, due to his inability to handle business troubles?. Nachum was committed to a mental institution in Germony, later to be given to a "Wunderrabbi" in Russion Poland. Nachum died 1910, ". . noch immer in denselben Umgebung, in geistiger Umnachtung, ohne jemals seinen Sohn ... gesehen zu haben. ${ }^{10}$

Maria, an overprotective mother, was successful in convincing the town of Brody that her husbend had hanged himself. The extreme concern she showed for her son's well-being, to the point of escorting him to school everyday, woiting the five hours until his classes were finished, and then wolking him home ogoin, wos in fact to keep him from ever having to confront the topic of his father. "Sie wollte nicht, doB inr Sohn yom Tod seines Vaters und dessen Hintergrund erfuhr."11

The absence of ofother is something Roth neyer ceme to terms with. To fill the void regording his poternal origins he invented numerous teles. Some descriptions he used frequently depict his fother os on Austrion

Bronsen, Eine Biogrophie, 91.

9 Bronsen writes that the exact circumstances concerning his illness connot be determined. See Bronsen, Eine Biogrophie, 41.

10 Bronsen, Eine Biographie, 42.

11. Bronsen, Eine Biographie, 67. 
officer, o Polish Count, o Viennese pointer, on irresponsible olcoholic given to melancholio and a high civil servant. In a possage written to Stanley Kunitz, Roth claims, "I was born in ... Schwabendorf, the son of a Russian Jewess and on Austrion."12 In o letter to Otto Forst-Batteglio in 1932 he wrote, "Ich bin der Sohn eines österreichischen Eisenbehnbeemten (frühzeitig pensioniert und Im Wohnheim gestorben) und einer russisch-polnischen Jüdin,"13 while to Blanche Gidon, o friend in Paris, he wrote, "d'un père outrichien (employe d'etat, peintre, elcoolique, devenu fou avent ma naissance."14 Still onother story he told to his publisher Gustov Kiepenheuer in 1930:

Meine Mutter wor eine Jadin von kroftiger, erdnoher, slewischer Struktur. ... Sie hotte kein Geld und keinen Mann. Denn mein Vater, der sie eines Toges noch dem Westen nahm, wohrscheinlich nur, um mich zu zeugen, ließ sie in Kattowitz allein und verschwond ouf Nimmerwiedersehen. Er muB ein merkwürdiger Mensch gewesen sein, ein Österreicher yom Schlog der Schlowiner, er verschwendete viel, trank wahrscheinlich und starb, als ich sechzehn Jahre alt wor....15

As a writer, Roth also created a number of fothers and sons as moin charocters. His repeated use of the father-figure motiv and its importence will be explored in the following chopters.

In 1913, ofter graduating from the Gymnesium, Roth left Brody. After - short sojourn to the University in Lemberg, he set out for Vienne, where he

12 Stenley Kunitz and Howard Haycraft; eds., Irentieth Century Authors (New York: H.W. Wilson,1942): 1204.

13 Hermonn Kesten, Joseph Roth: Briefe 1911-1939 ( Koاn, W. Ger.: Kiepenheuer, 1956): 239.

14 Kesten, Briefe, 313.

15 Kesten, Briefe, 165. 
arrived shortly before the outbreak of World Wor I. Leoving and starting over again wos one of the means Roth adopted to make life manageable. The Vienne which he encountered was still the city of culture, grondeur, ond great ortistic expression. For the Viennese middle class it wos still o time of securlty and lightheortedness. The orts were in full bloom with: the otonal music of Arnold Schonnberg, Alban Berg and Anton Webern; the seeds of Expressionism evident in the works of Oscar Kokoschka; and the revolutionary psychoenalytical writings of Sigmund Freud. In the summer semester of 1914, enrolled ot the University of Vienno, Roth begen his studies in Germanistlk. Wolter Brecht, 16 a professor of German literature, soon become Roth's mentor. ". . durch Professor Brecht einen der wenigen bedeutsemen Einflússe in seinem Leben; durch ihn erwachte in Roth die Liebe zur osterreichischen Literotur und zur österreichischen Wesensart."17

In the years 1914-1916 Roth was successful in publishing his first poems, short stories and essays in österreichs lllustrierter Zeitung. According to his friend from the university, Joszef Wittlin, most of the works from this time were lost in World Wor II. It was during these years, while the Monerchy approached its dissolution, that Roth digested his new impressions and experienced and acquired numerous viennese quelities. For a Jew, from the poor town of Brody, who grew up without a father, Vienna with its cultured way of life represented the "world". In the midst of the city's

16 Walter Brecht, who is of ten mistakenly quoted to be the older brother of Berhold Brecht, wos in reality of no relotion. See: Fritz Hackert, "Joseph Roth: Zur Biogrophie," Deutsche Vierteljohrsschrift für Litereturwissenscheft und Geistesgeschichte 43 (1969): 163.

17 Bronsen, Eine Blographie, 131. 
mognetism Roth soon sensed its problems: political unrest, bloody student demonstrations, constant tensions between the nationalities.

On May 31, 1916 Roth took the step that would lead him oway from university life, never to return to it again. With his close friend, Joszef Wittlin, he voluntorily enlisted in the militery. Unlike others at the outbreak of the war, they took a pacifistic stand and felt only the military and government wanted this wor but the clvilions, who suffered under it, reluctantly had to bear the consequences. However, with the incoming reports of deeths and massacres, Roth and Wittlin hardened their views. No longer could they remain uninvolved bystanders.

After the army rejected them twice becouse of physical disobilities, they voluntarily enlisted in the 21st Feldjoger Battalion. They felt that if for no other reoson, ". . die Kriegserlebnisse, on denen sie teilhoben würden, sollten eines Tages in ihren Schriftstellerischen Werken ihren Niederschlog finden."18 The time served proved to be unpleasent to soy the least. Unaccustomed to the strains of military discipline, specifically the humiliating treatment by superiors, their morale weakened. The friends were separated, not to meet again until the foll of 1918. Roth remained in Vienne until the spring of 1917, when he was assigned to Galicio. Roth's account of events during his military service vary in much the same way os do the stories of his father. To quote Dayid Bronsen, "Diesen Zeitabschnitt seines Militordienstes umrankte Roth mit den forbigen Blüten seiner Fabulierkunst."19 One of the many tales reads os follows:

18 David Bronsen, "Joseph Roths Kriegsdienst 1916-1918," Schweizer Monatshefte $49(1969 / 70)$ : 572.

19 Bronsen, Eine Blographie, 168. 
... the war broke out. I volunteered out of patriotism, but did not get to the front until 1916. I stoyed there eight months, become sick, and on account of my knowledge of the Russian language and the Russion country was sent to the Commission of Occupation in the Ukroine. I become on officer, ond intended to stoy o soldier all my life. But then the revolution suprised me in Shmirinka. The revolting soldiers did not let me depert with the lest train. I started to hike home, reached the former Russian border ofter a fortnight, wos captured by Ukroinian troops, stayed prisoner for two months, fled, and of ter many detours got to Vienna. 20

In my research I found nothing to substantiate his rank as an officer, his being coptured or his obility to speak Russien. From letters written during 1916-1918 to his cousin Poulo Grübel, one can ascertain that he was ossigned to on outpost in East Golcia as a "Einjuhriger Freiwilliger", o rank given to those who had an Abitur or the equivalent. What becomes clear in the dubious heroic tales is that Roth's patriotism and yearning for the old AustroHungarion Monarchy grew.

In November 1918 the Empire collapsed. The Vienne to which Roth returned in December 1918 wos one of political chaos, unemployment and an uncertain future. No longer hopeful of becoming a professor, he never resumed his university studies. Roth, in utter poverty, had to decide what his next step would be. During the war he had managed to publish articles in the doily newspoper Der Abend and the weekly mogazine Der Frlede. Upon suggestions from Fred Heller, the editor of a Viennese newspeper, he now decided to try his hand at being a reporter. At the time he did not realize that journalism, in one form or onother, would follow him until his death. In 1919, the year Austrio become o Republic, Roth began to write for Der Neue 
Ieg. Within a short time his finencial troubles ware resolved and he quickly become part of the famed Viennese "Koffeehous" scene. In the same year he met the seventeen year old friedl Reichler, whom he would eventuelly marry. After only thirteen months of existing, Der Neve Teg closed its doors. Roth egain had to ask himself what to do next. However, from this time on he need not fear the future. He had esteblished himself as o valued journalist and could always sell his feuilletons ond articles. With this feeling of security, Roth left for Berlin in the summer of 1920, where he worked for a number of dolly newspopers until his return to Vienno May 2, 1922. Three days loter he martied Friedl.

By nature o shy woman, Friedl sought strength ond support, which Roth more than willingly gave. "Er bezeigte ihr große Aufmerksamkeit, ging ouf ihre Sorgen ein, und war ... zart und verstandnisvoll."21 She in turn had a megical effect on Roth. The drinking hobit, acquired during his militery years, wos easily controlled when in the compeny of Friedl.

It was not long of ter their marriage that Friedl's mental state began to deteriorate. From 1924 on she visited numerous doctors and hospitels. Their marriage came to o tragic end in 1933 when she was committed to the 'Londes- Hell- and Pflegeanstolt für Geistes- und Nervenkronke', where she was diagnosed os o schizophrenic. On April 12, 1933 Roth wrote, "Mein ganzes Leben ist ruiniert. Ich habe vierzehn Jahre umsonst georbeitet und gelebt. ... Am Leben liegt mir gar nichts mehr."22 The irony of the above statement lies in the foct thet the years from 1924 to 1934 proved to be his most productive.

21 Bronsen, Eine Biographie, 205.

22 Bronsen, Eine Biographie, 349. 
From 1923-1925 he primarily worked os a travelling reporter for the Frankfurter zeitung. In 1924 his first two novels, Hotel Savoy and Die Rebellion met with greot success. His trovels took him to France, the Bolkans, Russia, Germany and Poland, where he wrote most of his work on tables in coffee houses and desks in hotel rooms. Although always on the move, Roth was no happy man. In a letter dated January 1, 1930 he wrote,

Mit ... der seelischen Belostung muß man allein fertig werden. Und da hilft es leider nicht, daß man selbst ein Schriftsteller ist. Dos ist man offiziell and privot ist man ein ganz kleiner Teufel, der schwerer schleppt ols ein Straßenbahnschaffner. Die Zeit ollein und nicht die Begabung kann uns die Distonz geben, und ich habe nicht viel Zeit mehr. Zehn Jahre meiner Ehe haben mir vierzig bedeutet und meine natürliche Neigung, ein Greis zu sein, unterstūtzt dos öußere Unglück in einer schrecklichen Weise. ${ }^{23}$

Juden ouf Wenderscheft and Die Flucht ohne Ende were published in 1927, one year loter Zipoer und sein Voter, and in 1929 Rechts und Links and Der Stumme Prophet. His next novel, Hiob published in 1930, wos os internotionally successful as his 1932 novel, Rodetzkymarsch, would be. By 1934 , when his next novel, Torabes, wos published, Roth wos suffering from deep depression, dependency on alcohol and living in exile.

On Jenuary 30, 1933, the doy Adolf Hitler took power, Roth left Germany to live his remoining six years in exile. Roth no longer lied to himself, he foced the reality of Nazism, os is expressed in a letter to Stephen Zweig, doted February 1933.

Inzwischen wird es Ihnen klor sein, doß wir großen Kotostrophen oustrelben. Abgesehen von den privaten - unsere literorische und moterielle Existenz ist jo vernichtet - führt des Genze zum neuen Krieg. Ich gebe keinen Heller mehr für unser Leben. Es ist gelungen,

23 Bronsen, Eine Biograghie, 349. 
die Borborei regieren zu lassen. Mochen Sie sich keine Illusionen. Die Hölle regiert. 24

Despite his continuous depression and bouts with olcohol, Roth continued to write articles for various newspapers in Austrio and France and to publish ot least one book o yeor until his death: in 1934 Iarabos and Der Antichrist, 1935 Die Hundert Toge, 1936 Die Beichte eines Mörders, 1937 Das Falsche Gewicht, 1938 Die Kapuzinergruft, and in 1939 Die Geschichte von der 1002. Nocht. It is cleor that while the substance of his life shriveled his literory creation served os the only saviour.

The annexation of Austrio by Germany, on March 13, 1938, was the final hordship Roth would face. With his dream for the restorotion of Habsburg power shattered, his physical and mental health deterioroted.

Roth tronk mehr und mehr.... Er wos aufgeschwemmt, sein Blick wässrig, sein Gang unsicher. Er litt on Anföllen von Verfolgungswahn, peitschendem Schuldgefühl und Blindheit. Der Arzt bestond ouf Milch; do goß Roth Pernod hinein. 25 Joseph Roth died Moy 27, 1939 in the Hospital Neckar in Paris. Cause of deoth: alcoholism? pneumonia? o broken heort?

On Moy 28th 1939 several of Roth's closest friends met ot the Cofé Tournon to decide on what type of religious ceremony should be corried out ot the funeral. Since no evidence of Roth's boptism was of hand, his Cotholic friends had to agree on only a "quesi-Cotholic" burial, while his Jewish friends planned to soy Koddisch, the Hebrew proyer for the dead. On May 30, 1939, ot the Thiais cemetery, in the south of Poris, Joseph Roth was loid to rest. Roth's lifelong conflicting loyalties and contradictory impressions

24 Kesten, Briefe, 249.

25 Ludwig Marcuse, "Die neue Unsachlichkelt," Die Zeit 20.36 (1965): 11. 
were more than evident on this day, as Habsburg loyalists, Communists, Jews and Catholics were among the many who flocked to his graveside. 
CHAPTER III

\section{RADETZKYMARSCH}

World Wor I was o turning point for many authors; it brought to an end one world and painted an uncertain picture for the future. For Roth the fall of the Empire was more then this: losing the Monorchy was for him o crisis, his most intense experience. In a letter to Otto Forst de Bettogio he proclaimed:

Mein stơrkstes Erlebnis wor der Krieg und der Untergang meines Voterlandes, des einzigen, des ich je besessen: die ōsterreichischungarische Monarchie. 1

The present chepter will explore and analyze Roth's image of the Habsburg Empire as created in his novel Radetzkymarsch (1932).

Badetzkymersch relates the lives of three generations of the Trotta family -- of Joseph, his son Franz, and his grandson Carl Joseph -- during the last fifty-seven years of the Austro-Hungarion Empire. The novel begins with the Battle of Solferino and ends with the death of Franz Joseph I in 1916. As will be shown, this fomily chronicle could optly corry the some subtitle as Thomas Mann's Buddenbraoks: 'Verfall einer Familie'.

The novel begins with the historical Bottle of Solferino in 1859, Where Austrian troops suffered serious defeots by the united armies of Italy and France. It wos this bettle that ". .zum erstenmal den Untergang der

1 Kesten, Briefe, 240. 
kaiser- und kőniglichen Monorchie angekündigt hotte. 2 Young Joseph Trotto, o Slovene, is an infentry lieutenent in commend of a platoon at Solferino. During the battle he is shot while seving the life of the young Emperor Franz Joseph I. For his heroic deed.he is promoted to coptain, decorated with the Order of Mario Therese, and the prefix 'von' is added to his name. Ceptein Joseph Trotto von Sipolje marries, has a son and settles down to the normol life of on officer, until one dey he reads a glorified and falsified version of his rescue of Franz Joseph $I$ in his son's schoolbook. Outraged ot the misrepresentation of facts, he protests until he is granted an oudience with the Emperor. But here he is let down. Unable to accept the lie, he feels betroyed and resigns. The Monerchy however discharges him as major and bestows upon him the title of Beron. The first chepter ends with his death; the remeining twenty deal with Frenz and Cerl Joseph.

Franz Trotte, forbidden by his fother to join the army, studies low and enters the civil service, eventually to become Royal Chief District Commissioner in Morovio. Fronz von Trotte and Sipolje, o foithful servant to the Emperor, insists his son, Carl Joseph, go to military school. Corl Joseph however cen only live in the shadow of his grendfother. He is too weak and sensitive to cerry on the tradition of the family. He becomes estrenged from his fellow officers, and cerries terrible feelings of guilt obout his involvement in the deaths of people close to him. The first death he experieces is that of Frou Sleme, the gendermerle sergeant's wife with whom he had had an offoir. Although she dies in childbirth, Carl blemes

2 Joseph Roth, Redetzkymersch, (Kőln, W. Ger.: Kiepenheuer, 1950): 319. Literary quotes in this chopter ore all token from Radetzkymarsch. Page numbers will hereafter oppear in parentheses directly ofter the quote. 
himself for her death. "Ihre Worte woren zörtlich, sie war eine Mutter, sie hat mich geliebt, sie ist gestorben! Es wor klor, doß er Schuld on inrem Tode trug." (49) The next deoth he is indirectly involved with is that of his only friend, Max Demant, the regimental doctor. Wrongly accused of hoving had an offair with Max's wife, Evo, Corl Joseph ogoin feels himself to be the couse of Max's tragic death. "Und er (Corl Joseph) fühlte, daß die Toten die Lebenden riefen, und ihm war, ols würde er selbst morgen schon ... zum Duell ontreten. Zum Duell antreten und follen. Fallen und sterben." (114) Max and Captain Tattenbech, the instigator of the rumors concerning Corl Joseph and Frou Dement, both die in the duel and Corl Joseph's inability to cope with life is intensified. He osks for a transfer and is reassigned to on infontry bottolion in the northeosternmost corner of the Monorchy, the Austro-Russion borderland. Here ogain he faces a bleok environment and becomes even more disillusioned.

Der Leutnant Trotto ober, empfindlicher ols seine Kamaraden, trouriger als sie und in der Seele des ståndige Echo der rouschenden dunklen Fittiche des Todes, dem er schon zweimal begegnet war....(160)

This time his depression leads him to take up the "corrupt" activities of drinking and gambling. On a three day pass to Vienno, Corl Joseph meets his second lover, Frou Valerie von TauBig. She is a middle-aged woman who keeps herself 'young' by seducing young soldiers. Upon returning from Vienne, Corl Joseph is ordered to break up o meeting of the striking workers of o bristle foctory. With o plotoon of soldiers he confronts the workers, shots ore fired, workers ore killed and Corl Joseph is injured. Although he could not be held responsible for the death of the workmen, he thinks of leaving the army and osks his fother for permission. 
This news from his son weighs heavily on the District Commissioner's heort.

. . die Erwbgerund seínes Sohnes, die Armee zu verlossen, wirkte ouf Herrn yon Trotte etwo so, wie wenn er eine Mitteilung von der gesamten kaiser- und königlichen Armee erhalten hötte, daß sie gesonnen sei, sich oufzulösen. Alles, olles in der Welt schien seinen Sinn verloren zu haben. Der Untergeng der Welt schien ongebrochenl (274)

His eventual response is to ollow Corl Joseph to determine his own future. Ready to resign, Corl must however face the lorge debt he has incurred through gombling and borrowing in order to visit Frau von TouBig in Vienno. Unable to even begin to poy back the 6000 Crowns, he once again has to write to his father for help. Franz, unable to produce such an amount, has to visit the Emperor. The Hero of Solferino comes to the oid of the Trottes. The family honor is soved.

With his debts token core of, Corl Joseph resigns from the ormy on the doy his regiment receives word that the heir to the throne was murdered of Sarojevo. And with the eruption of the wor, ". . der Krieg, ouf den er sich schon ols Siebenjähriger vorbereitet hatte," (361) Corl Joseph rejoins his unit and marchs northword to the Wolocyske frontier. Not long of ter the war begon, he is hit in the heod with o bullet ond is killed while fetching woter for his men. With his son's death and his office terminated, Franz Trotto's world olso ends. He dies November 21, 1916 within hours after the death of the Emperor.

Decey and the fall of preeminence, which begin of the outset of Redetzkymarsch, determine the course of the novel. The reeder is never given a true picture of the Monarchy before the decay begen. Although the original ressons for the Monarchy's dissolution are never stated, Roth's image is quite 
clear. Everything -- events, chorocters, pictures, scenery -- is plogued by decodence and downfall. A feeling of staleness lingers over the novel.

Roth's imoge of the Empire is set in the lives ond fotes of the Trottos. Their fate is symbolically tied to that of the Monorchy. Each fictional cherocter in Radetzkymersch represents o certoin ospect of Roth's declining Monorchy.

The grondfother, Joseph Trotte, initiates good fortune for the fomily by soving Emperor Fronz Joseph's life. Franz Joseph I had come to inspect the troops at the Battle of Solferino. Aware of snipers in the orea, Lieutenont Trotto pushes the Emperor to the ground and cought the bullet, oimed for the Emperor's heort, in the left shoulder. As o potriot he equates the life of the Emperor with thot of his regiment, the ormy, the stote, in foct the enitre world. His heroic deed is reworded greotly. But os the son of simple Slovenian peosents, he never feels ot eose with his new rank ond title.

...(D)er geodelte Houptmenn Trotto (verlor) des Gleichgewicht, . . . und inm wor, ols wöre er von nun on sein Leben long verurteilt, in fremden Stiefeln ouf einem glotten Boden $\mathrm{zu}$ wondeln, von heimlichen Reden verfolgt und von scheuen Blicken erwortet. (11)

He feels detached from his forefothers, and soon realizes the weokness of the prevalling morol and social order. Unable to accept o trumped-up version of his rescue of the Emperor, he insists on an audience with Franz Joseph. He is informed ot the meeting that, for political reosons, the story would not be chenged. He leeves the meeting disillusioned and realizes the Emperor's totel dependency on his ministers.

As steted before, Joseph dies ot the end of chopter one, but he is kept olive throughout the novel in the minds of the characters, who ore closely connected with him. He is their bridge to the post. His portroit reminds them 
of their duty and honor, it becomes their icon. Franz and the fomily's servant, Jacques, both wanted the portrait close to them in their finol hours. Carl Joseph had an even stronger attraction to the portrait. Even though he had never met his grondfother, he feels closer to the portroit than to his fother. "... (Er fühite) sich ols der Enkel seines Großvaters, nicht ols der Sohn seines Vaters. ..." (74) Corl Joseph often feels his grandfather's eyes on his back. "Corl Joseph fühite den gebieterischen Blick des GroBvaters im Nocken. Der Held von Solferino diktierte dem zoghoften Enkel bündige Entschlossenheit."(113) Joseph and his generation symbolize the birth of the "Age of Weakness".

Fronz Trotto, forbidden by his fother to join the ormy, is the district commissioner in Morovia. He is a model bureaucrat, but lacks the strength to foce reality until the death of his son makes him conscious of the collapse of his world.

Franz is awore of his title and his superior social status. Bandmaster Nechwal is a men of the world in the eyes of young Corl Joseph, but to Distict Commissioner Trotto he is nothing more than the director of the band, which plays weekly in front of the Trotto house. And at every Sunday reception the same conversotion between Herr Nechwol and Herr Trotto could be heard.

"Ich bin entzúckt von Ihrem Konzert", sagte Herr von Trotta, heute wie jeden Sonntag.... Herr Nechwal verbeugte . sich. ... "Wie geht es Ihrer Frou Gemahlin?" fragte Herr von Trotto regelmäBig. Seit Johren stellte or diese Froge. Er hatte Frou Nechwol nie gesehen, er wünschte ouch nicht, der "Frau ous einfachen Verhältnissen" jemals zu begegnen. ... Und wie geht es Ihren Kindern?" fragte Herr von Trotto, der immer vergeB, ob es Sơhne oder Töchter woren. "Der Álteste lernt gutl" segte der Kopellmeister. "Wird wohl Musiker?" frogte Herr von Trotto. . . . Eine Woche später hatte er alles vergessen. Man merkte sich nicht die Kinder des Kapellmeisters. (38) 
A second example of his renk consciousness is found in the cose of his brother-in-low, Stensky. Fronz wos unwilling to associote with him becouse he had morried someone from the "lower" class.

"Wie sieht er übrigens aus, der gute Stansky?" (frogte Herr von Trotto).... Ich hab inn zuletzt vor neunzehn Johren gesehen. Do wor er noch Oberleutnent. Schon verliebt in diese Koppelmann. Unheilbart Die Geschichte wor fost fotal. Verliebt wor er halt in eine Koppelmenn. Er sproch diesen Nomen louter ols dos übrige und mit einer deutlichen Zbsur zwischen den beiden Teilen. (57)

Franz's strict odherence to the closs system leoves him o lonely mon, o man unable and unwilling to show his son any feeling of his love. That is not to say that Franz does not love Corl Joseph. On the contery, he slowly begins to live for the sake of his son, so much so that when Corl dies, his existence turns brittle. Feelings of wormth ore nonexistent in this fother-son relotionship. From the outset Fronz is the mester, Corl his subject. Fronz dominates Corl. The reader is first introduced to the fifteen-yeer-old Cerl, who is home on leove from covalry cadet school. Their first meeting porallels a trial interrogotion. Promptly ot 9:00, sitting opposite his son, Fronz would osk the questions ond Corl would begin slowly to give on occount of all that had happened during the previous year. At 10:30 Corl would think to himself, "Anderthalb Stunden ging noch die Prüfung. Es konnte dem Alten einfollen, Geschichte des Altertums zu prüfen oder germenische Mythologie."(32) The questioning stopped ot 11:00, ot which time lunch was served. Corl, still unable to relex, would eat as much and as quickly os Fronz prescribed.

It is not clear until the end of the novel how close the fother-son relationship is. I believe that the reserved manner in which Roth chose to portray their relotionship points out that the lack of warmth does not stem 
from a lack of emotion, but rother a lack of communication. The feelings were alive, but suppressed. Franz kept his thoughts to himself. On his visit to see Corl ot the front, he tells Corl of the deoth of their foithful butler, Jecques, but cen not express his true thoughts.

...er sagte nicht, wie er gewollt hatte: "Ich hab dich lieb, mein Sohn!", sondern" "Er ist sehr leicht gestorben! Es wor ein echter Maiabend, und alle Vögel haben gepfiffen. ... Jacques hat alle Stiefel geputzt. Dann erst ist er gestorben, im Hof, ouf der Bonkl" (181-82)

The relationship between Franz and Skowronnek, a civilian doctor, olso suffers from the same problems. They regualrly meet at the local cofé to ploy chess, but are unable to establish the intimate relationship they both long for. Fronz's inability to communicate is also opperent in his relotion to Moser, o degenerate artist. They were frlends in their youth ond Moser had even painted Joseph's portrait. But during their meeting in the "Volksgarten" it is obylous they no longer have enything in common. Franz tolerotes Moser, but ovoids his friendship by typically offering money.

Fronz is duty conscious and loyol, but as an Austrion official, unable to odmit the imperfection of the Monarchy. When Carl Joseph tells his father of his plan to resign, only then does Franz begin to see the light. "Die Monarchie ist tot, sie ist tot!" schrle (Carl) und blieb still. "Wahrscheinlich!" murmelte der Bezirkshouptmonn, ohne den Kopf zu heben." (351)

Carl Joseph Trotte is the prototype of Roth's non-hero. His cheracter represents the decay of Austrion life in the final years of the Monarchy. On his father's wishes he joins the ormy, but is for from being o model soldier. $\mathrm{He}$ is possively corried in his career by his grandfother's legend. Wherees the Hero of Solferino saved the Emperor's life, Corl can only seve Franz Joseph's portrait from o bordello. A skeptical, melencholic, week man he is unable to 
put his life in to order and deal with the present. He lives in the past. Carl is a static cheracter, he does not develop. Roth only gives an account of his changing feelings. Melancholy, guilt, olienation, fear, homesickness, nostalgie and shame determine his life. These feelings intensify his life, but suffocete his will to live. "Seine Müdigkeit, sein Weltschmerz und eine Todessehnsucht machen ihn zu einem typischen Repräsententen der Fin-desiècle Dekedenz. . . . 3 Corl represents one of the many inactive unperticipating side-line abservers of the Dual Monerchy. He is cought between two worlds: the old world of the ageing Monarch, with its devoted servents, and the new world of individualism and nationalism, the fighters of which brought about the foll of the Empire.

The lack of warmth and communicotion evident in the father-son relationship is also characteristic of Carl's social relationships. The regimental doctor, Max Demant, is the only character Carl recognizes as o friend. They are drawn to one another becouse they both stand outside of the officers' circle. They shore the seme feelings obout the militery and are both described as weak grandchildren. Dut of their inability to master life a band is created. This bond quickly weokens when Mox is led to believe in o love affair between his wife, Eva, and Carl. Max confronts Carl and Carl swears on his honor that there is nothing to be suspicious of and they shake hands. Although their feelings for one another ore mutual, they con not overcome the block in communicotion.

Lange, lange möchten sie so nebeneinander marschieren. Jeder yon den belden hotte irgendein Wort zu sogen, und beide schweigen. Ein Wort, ein Wort ist leicht gesprochen. Es is nicht gesprochen! --

3 Hans Jürgen Böning, Joseph Roths 'Rodetzkymorsch', (München, W. Ger:: Wilhelm Fink, 1968): 76. 
Zum letzten Mol, denkt der Leutnent, zum letzten Mol gehn wir so nebeneinander her. (104-5)

The other relationship he attempts to establish was with his orderly. Onufrij, a simple Slavic peasant, is devoted to Carl. His loyalty goes so for that he sells his only piece of land in order to help Trotta out of a huge gambling debt, but Trotte refuses the money. Although he is aware of Onufrij's feelings, he could never soy the right words to establish the friendship.

Carl's love affairs are also marked by estrangement. They are not genuine human relationships, but both affairs characterized by sexual exploitation. Frau Slame, the first lover, seduces Corl, while her husbend is owoy at work. Every second doy at 4:00 Cerl appears ot her door. Promptly at 7:00 he leaves. On hearing of her death he visits Sergeent Slame to poy his respects. The meeting is owkword and locks openness.

"Herzliches Beileid, Herr Slamal" ... "Sle wor eine brove Frou, die selige Frou Slomal" sogt der Leutnant. Der Wachtmeister sogt, ... "Sle ist schön gewesen, Herr Baron haben sie jo gekonnt." "Ich hobe sie gekannt, Ihre Frou Gemohlin." (64)

Although Slame was awore of the offoir he keeps his emotions under control and says nothing of it. All he cen do is to show Corl their wedding plcture. Carl looks at the picture and suddenly becomes indifferent. The offoir was oyer, as though it never had existed. "Man sagt etwes Nettes von einer Toten, im Angesicht des Witwers, dem mon kondoliert. (Corl) fühlt sich sofort befreit und von der Toten geschieden, als wăre olles ousgelöscht." (67) Cori bids Slame forewell. As he opens the garden gote Slame colls to him and hands over o package. The pockege contains the love letters addressed to Frou Slamo. 
"Dos ist für Sie, Herr Baronl" . . "Bitte um Entschuldigung! Der Herr Bezirkshouptmann hat's ongeordnet. Ich hab's damals gleich hingebrocht. Der Herr Bezirkshauptmann hat's schnell überflogen und gesagt, ich soll's persőnlich übergeben!" (68)

With this scene, Roth again points to the oworeness of sociol status of the time ond its inequity.Corl's second of fair is with Frou von TouBig, o middleoged woman, who lives in the past as Carl. She seduces young soldiers to stoy young.

Jeder junge Mann, den Frou von TouBig in inre Arme nahm, war der langersennte Gost... . Sie lebte jo gar nicht; sle wortete jo nurt Einen noch dem ondern soh sie davongehen.... Allmoblich gewöhnte sie sich deron, Mănner kommen und gehen zu sehen. .. . Frou von Toußig stellte dem nohenden Alter junge Mănner entgegen, wie Dämme. Aus Angst vor ihrem erkennenden Blick ging sie mit geschlossen Augen in jedes ihrer sogenannten Abenteuer. (219)

She does not love Carl, she loves his youth. He is just one of the many Lieutenents. For Corl, Frou yon Toußig was, as Frou Sleme had been, a mother figure. "Der Leutnent log on ihrer Brust wie ein Kind" (222) on the first night they spent together. They do not have o true relationship. In the Illusion of a love of fair they ottempt to satisfy their own needs. Her passion to be young forever is as urgent os his to be loved.

Corl Joseph Trotte dies while getting woter for his men. This unsoldierly death fits his disillusioned life. Corl stands os Roth's main symbol of the decline of the Empire. A men who yearns for the native soll of his peosant forefothers, Corl is crushed by the pressures of o modern age.

Roth's three "heros" -- Joseph, Franz, Corl Joseph -- ore not only individuels, they ore representotives of their time. The Hero of Solferino is the yordstick by which Franz and Carl Joseph meosure themselves. They goin their significance in so for os they deviote or stoy close to the Joseph model. Even though Joseph dies in chapter one, his character is kept alive throughout 
the plot. Through Joseph's immortality, Roth constontly calls attention to the differences between the old and the new Monorchy. Through contrasting and peralleling these characters, Roth differentiotes between the ideal and the real, the pest and the present. More specifically, the decay of the Trotte family is paralleled with the deterioration of the Empire.

There are number of secondary characters who olso play on importent role in Roth's image of the Empire. In Rodetzkymarsch, Roth equates the existence of the Monerchy with the life of the Emperor. Though only in the background, Fronz Joseph I is constantly present. Roth depicts him os a human being, an elderly gentleman conscious of the deterioration of his Empire.

Durch den Feldstecher sah Franz Joseph die Bewegungen jedes einzelnen Zuges, ein paar Minuten lang fahlte er Stolz auf seine Armee und ein poor Minuten auch Bedauern über ihren Verlust. Denn er soh sie schon zerschlogen und verstreut, oufgeteilt unter den vielen Volkern seines weiten Reiches. Ihm ging die große goldene Sonne der Habsburger unter, zerschmettert am Urgrund der Welten, zerfiel in mehrere kleine Sonnenkügelchen, die wieder als selbststăndige Gestime selbstständigen Nationen zu leuchten hotten. Es poBt ihnen halt immer, von mir regiert zu werdenl dachte her Alte. Do kann man nix machen! făgte er im stillen hinzu. Denn er war ein Österreicher. (259-60)

Although each fomily member stands in a different relation to the Franz Joseph I, he is the main source of meaning and value for the Trottas. Franz in fact feels himself a brother to the Emperor. Roth emphasizes the bond by hoving Franz look like his sovereign.

Sie woren wie zwei Brüder. Ein Fremder, der sie ein diesem Augenblick erblickt hätte, wäre imstonde gewesen, sie für zwei Brüder zu halten. Ihre weiBen Backenbarte, ihre obfollenden schmolen Schultern, ihr gleiches körperliches Maß erweckten in beiden den Eindruck, doß sie ihren eigenen Spiegelbildern gegenüberstanden. Und der eine gloubte, er hätte sich in einen 
Bezirkshouptmann verwondelt. Und der andere gloubte, er hätte sich in den Koiser verwandelt. (325)

The death of Frenz Joseph I signifies the death of the Trotto's. The Trottas could not outlive the Emperor and the Emperor could not outlive the Trottas, while neither could witness the dissolution of the Monerchy.

Count Wojciech Chojnicki is another significant character. Although not a soldier, he lives among the officers of Carl Joseph's infantry regiment. As a delegate to the Imperial Parliament he becomes Roth's political mouthpiece. Through this character Roth portrays the Austrion oristocrat, who held high political office, but was unwilling to perform the duties of the office. He is the demoralized noble. Chojnicki does almost anything to assure his reelection, but never once takes an active part during Parliament's sessions. He is the prophet of doom, whose outspoken views tell of the Empire's impending deterioration.

Unglaubig, spōttisch, furchtlos und ohne Bedenken pflegte Chojnicki zu sogen, der Koiser sei ein gedankenloser Greis, die Regierung eine Bende von Trotteln, der Reichsrot, eine Versommlung gutgläubiger und pathetischer Idioten, die steotlichen behörden bestechlich, feige und foul.... "Dieses Reich muß untergehen. Sobold der Kaiser die Augen schließt, zerfollen wir in hundert Stücke." (159)

In a meeting with Franz Trotto he gives a detailed account of the weokness of the Empire. He points out that Franz Joseph I and his civil servents can not reconcile the national aspirations of the Empire's peoples. Hobsburg power, he offirms is founded on the belief in the divine right of kings and thus can not survive in an age of skepticism.

Vielleicht hatte Chojnicki richtig gesprochen, und sie woren in der Tat alle nicht mehr do: das Voterland nicht und nicht der Bezirkshouptmenn und nicht der Sohn! ... "Die Zeit, (erwiderte Chojnicki), will uns nicht mehrl Diese zeit will sich erst 
selbstständige Notionalstaoten schaffen! Man gloubt nicht mehr on Gott. Die neue Religion ist der Notionalismus. Die Välker gehn nicht mehr in die Kirchen. Sie gehn in nationale Vereine. Die Monarchie, unsere Monorchie, ist gegrundet ouf der Frömmigkeit: ouf dem Glauben, doB Gott die Habsburger erwählt hat, über soundso viele christliche Vólker zu regieren. Unser Koiser ist ein weltlicher Bruder des Popstes, es ist Seine k. u. K. Apostolische Majestat, keine andere als er: apostolisch, keine andere Majestat in Europo so abhangig von der Gnade Gottes und vom Glauben der Völker an die Gnade Gottes. Der deutsche Kaiser regiert, wenn Gott inn verlabt, immer noch; eventuell von der Gnade der Nation. Der Kaiser von Üsterreich-Ungarn darf nicht von Gott verlassen werden. Nun aber hat ihn Gott verlassenl" (187-88)

Chojnicki recognized the primary couse of the fall of the Habsburg Monarchy. But more importantly he dored to voice his thoughts. Not long ofter the wor had begun, Count Chojnicki returns from the front an insane man. Franz Trotto is summoned to visit him in the hope that their meeting would improve the Count's condition. Ironically however, Chojnicki, in his insenity, is stlll able to recognize the political future of the Monerchy better than the District Commissioner.

"Setzen Sie sichl" sagte Chojnicki. "Ich habe Sie kommen lossen, um Innen etwas Wichtiges mitzuteilen. Verraten Sie es niemendem! AuBer Ihnen und mir weiB es heute kein Mensch: Der Alte stirbt!" "Woher wissen Sle das?" fragte Herr von Trotto. Chojnicki, immer noch on der Tar, hob den Finger gegen die Zimmerdecke, legte inn dann an die Lippen und sagte: "Von oben!" (378)

Like Roth, Chojnicki's despair for the Empire wos created out of feelings of genuine love for the state that was crumbling in front of him.

The majority of the officers in Rodetzkymarsch correspond similarly to the many phases of the Austro-Hungarion Empire, of which they are products. They are the stereotype of the officer and the gentleman: they proudly parade in unfform, they play wor games, they uphold their honor through duels, and they womanize. But behind this facede they are just os disillusloned as the 
soclety they live in. While in the borracks they lead the lethargic life to which their society privileges them. They tolk of wor, but ore blind to the essence of military life. Roth's most striking demonstrotion of their decadence happens during the officer's summer festival. The first feelings of Notionalism are made evident after they hear of the death of the heir to the throne at Sarajevo. The outspoken reactions of the officers demonstrate that the Austro-Hungarian Empire was no longer possible. The division among the officers symbolize the obsence of unity in the Empire.

The femole choracters that could have brought love ond wormth into the "Monnerwalt" of Radetzkymarsch live in the shadow. Corl Joseph's mother and grandmother died early, while the women of his love offoirs function as weak mother figures.

Alongside the characters Roth olso created o number of leitmotifs in Radetzkymarsch. The recurring themes of alcohol, death, letters and music emphasize his image of the deteriorated Monarchy. Most of the officers in Redetzkymarsch ottempt to drown their sorrows in olcohol. Through their drinking, ofolse sense of security develops. Carl Joseph reachs for the bottle to forget, to forget that which he could not forget. In drunkenness Corl escopes, life is easier to cope with. Alcohol washes away his conflicts. "Er wurde. . immer sonfter, je mehr er trank." (195)

Death is also a close friend to many of the characters. Nine cheracters -- Joseph's fother, Joseph, Frau Slamo, Max Demant, Jocques, Wogner, Corl Joseph, Franz, Fronz Joseph 1 -- die in Rodetzkymarsch. Death often shapes the thoughts of the characters and the foreshadowing of the nerrotor. As for the officers,

Alle fühlten, daß er den Tod angerufen hatte. Der Tod schwebte aber innen, und er war innen keineswegs vertraut. . . Domols 
wuBten sie noch nicht, deß jeder von ihnen, ohne Ausnahme, ein pear Jahre spotter mit dem Tod zusommentref fen sollte. (106)

Roth emphasizes the power of death even more in Carl Joseph's cheracter. His ardent desire for deoth is constantly reinforced by the death of the those "close" to him. With the deeth of Frau Slama, his youth was destroyed and "Vor inm lag also ein langes Leben voller Trauer." (49) He also lived to see the death of Max Dement, Jacques and Captain Wagner. His thoughts are plegued by these deaths. As he tells his fother, "Die Toten! Ich kann die Toten nicht vergessen! Voter, ich kann gar nichts vergessen! Vaterl" (195) On his numerous visits to the cemeteries he sees the graves as milemarkers of life. Roth describes the deaths of Jecques, Carl Joseph, the Emperor and Franz in great deteil. With the simultaneous deaths of Fronz Trotto and Franz Joseph I, Roth has Rodetzkymarsch symbolize the "Verfoll einer Fomilie," as well as the "Verfall einer Monorchie."

The character's solitary and withdrawn nature is also evident in the letter leitmotif. The leck of communication discussed eerlier is also menifested in Roth's use of letters. The Trotta-letters are short, formal and written regularly. And as the dialog, letter writing presents problems for the cherecters. It takes hours for the letters to be composed. The charecters find it hard to put their thoughts and problems on peper. Thus, the letters contain only facts, requests, orders and decisions. "Wenn er (Carl) seine gehorsamen Briefe schrieb, in denen so wehig stand, erwiderte man mit ein poor gemessenen Zeilen." (196)

Roth employs these techniques so that the reader is always awore of the lonely man, the man who suppresses his feelings and lives in a world -...(die) zum Untergang verurteilt (wor). This dark world he lives in - 
.. verdiente keinen onstondigen Bewohner mehr. Es hatte olso keinen Sinn, douerhaft zu lieben, zu heiraten und etwo Nochkommen zu zeugen." (218)

Radetzkymarsch owes its title to Austrian Field Marshal Josef Graf Rodetzky von Radetz, who at the age of eighty-two ployed a decisive role in the recovery of Austrio, more specifically, Lombordy, in 1848. Although Redetzky is mentioned once in the novel, it is Johann Strouss' musical composition, Rodetzky March, that is used as the leitmotif. The "Rodetzky Merch" is the military march of Austria; somewhat like "Preußens Glorio" for Prussio, "British Grenadiers" for Britoin, and "Stors and Stripes Forever"m for the United States. It is used as a symbol of power, os well as decoy. Once it was ployed by a militery band in front of the Trotto house. And as the sun shone of the brass instruments the March symbolized the "Voterland" for the young cadet, Carl Joseph. At onother time it was ployed around the red velvat and drunken men of Frou Resi's bordello. Amidst the smoke and dim lights, its meaning became distorted.

In Radetzkymarsch Roth has captured the age of the Dual Monerchy of Franz Joseph $I$ and the essence of the disintegrating life of its people. The reader gets the feeling, that beyond the political upheaval, the foll wos largely due to personol disillusionment and social alienation. The characters of this world dramo suffer from a fallure to imagine and a lock of energy. One can be sure that the decay of the Empire stemmed in part from the alienation of men like Franz Trotto, as well as the center and source of political power. Roth shows the Emperor himself disillusioned:

Und do wußte er, doß der Pater bald kommen würde. Und er bewegte seine Lippen und begann, wie man thn gelehrt hatte, als Knaben: "In Reue und Demut beichte ich meine Sünden..." Aber auch dos hörte man nicht mehr. Übrigens sah er gleich dorauf, daß der 
Kopuziner schon do wor. "Ich hab lang worten müssenl" sogte er. Dann überlegte er seine Sünden. "Hoffart!" fiel inm ein. "Hoffartig wor ich holtl" sogte er. Eine Sande noch der ondern ging er durch, wie sie im Katechismus standen. Ich bin zu longe Koiser gewesen! dochte er. Aber es kam ihm vor, doB er es laut gesagt hotte. "Alle Menschen müssen sterben. Auch der Koiser stirtt." Und es wor ihm zugleich, ols stürbe irgendwo, weit von hier, jener Tell von ihm, der koiserlich gewesen wor. "Der Krieg ist ouch eine Sündel" segte er lout. Aber der Priester hörte inn nicht. Franz Joseph wunderte sich oufs neue. Jeden Tog kamen die Verlustlisten, seit 1914 douerte der Krieg. "Schluß machenl" segte Franz Joseph. Mon hörte inn nicht. "Wör ich nur bei Solferio gefallen!" sagte er. Man hŏrte thn nicht. Vielleicht, dachte er, bin ich schon tot und rede als ein Toter. Desholb verstehen sie mich nicht. (380-81)

Roth masterfully speoks from the soul of his characters, who hove follen vicitms to Robert Musil's 'Kokonio'. With ocute insight he points the polyptych of the greying twilight of the once powerful and vitel AustroHungerion Empire.

4 A term invented by Robert Musil in Mann ohne Eigenschoften. It gets its meaning from the initials of the adjectives for the Dual Monarchy: kaiserlich and koniglich. 
CHAPTER IV

\section{DIE KAPUZINERGRUFT}

After Radetzkymarsch Roth witnessed Hitler's rise to power and left Austrio, never to return. During his years in exile he become, as o confirmed Monorchist, an outspoken supporter of the Habsburg claim to the throne. By the time he finished Die Kepuzinergruft in 1938, any and all hopes for the restorotion of Habsburg power were shattered. As a perallel and onochronistic sequel to Rodetzkymersch, Die Kopuzinergruft tells of the some lost generation, the same decaying world. Roth even chose to mirror the fate of Austria in the life of o Trotto agoin: Franz Ferdinand Trotta, a member of the bourgeois branch of the family.

The novel begins in 1913 and ends with the annexation of Austrio in 1938. Franz Ferdinend Trotto, grandnephew of the Hero of Solferino, is protegonist and nerrotor. He begins his story with an explenation of his relotionship to the "geodelten" Trottas, but quickly points out that his fother wos a rebel and o patriot. His father had wanted to reform and save the Hobsburgs. He wos soon suspected and fled to Americe, where he become financially successful. With his weolth he returned to Vienno to help "build" the Triod-Monerchy: Austriens, Hungorians, Slavs. On his deoth in 1912, Fronz Ferdinend was to become the heir of his wealth and political ideas. Roth makes an allusion here to Archduke Franz Ferdinend, the heir to the throne of Fronz Joseph I, who olso wanted to "build" the Triad-Monerchy. 
The young Fronz Ferdinand however is not interested in the political ideals of his fother. Since 1912, when he left the 21 st Joger Battalion, he has belonged to the reserves. With no need to work or study he lives with his mother and indulges in an idle existence. He enjoys a comfortable life omong his young oristocratic friends with whom he sheres "den skeptischen Leichtsinn, den melencholischen Fürwitz, die sūndhofte Fohrlössigkeit, die hochmūtige Verlorenheit, alle Anzeichen des Untergangs, den wir domals noch nicht kommen sohen." the nineteen-year-old Elisabeth Kovacs, but con not openly show his offection, for he feors the mockery of his friends.

In the summer of 1914 he goes to Zlotogrod, Gelicia to visit his peasent relative Joseph Branco Trotto and his friend, the coachman, Manes Reisiger. He spends his doys riding with Mones through the countryside and his nights with the officers of the 9th Drogoon regiment. When the wor breaks out Joseph and Manes enlist and march to the Russian bordertown Radziwillow, while Franz Ferdinand returns to Vienno. Upon his return he, like many of his firends, draws up o testament and announces his marrioge. The wor gives him the courage to overcome his weaknesses. His unconcerned friends disgust him now and he asks to be transferred to the regiment in which Joseph and Manes ore serving. As he says, "Ich wollte mit Joseph Branco zusammen sterben, mit Joseph Bronco, meinem Vetter, dem Kostonienbrater, und mit Manes Reisiger dem Fioker von Zlotogrod, und nicht mit Walzertänzern." (74)

After a disesterous one-day honeymoon he leaves Elisabeth to meet up with Joseph's regiment. Attacks from the Russian ormy keep them on the

1 Joseph Roth, Die Kapuzinergruft (Köln, W. Ger.: Kiepenheuer, 1972): 14. Literary quotes in this chapter ore all taken from Die Kopuzinergruft. Page numbers will hereafter appear in parentheses directly ofter the quote. 
move until the historical Bettle of Krosne-Busk, when one-third of their regiment is killed and another third, including Franz Ferdinand, Joseph Branco and Manes, is taken prisoner. Six months loter they arrive in Siberia. After a brief period of freedom in the house of Jan Baranovitsch, a fur trader, their friendship comes under strain. They eventually retum to the prisoner camp, their feelings toward one another grow cold and Franz Ferdinand is seperated from the others. Manes and Joseph manage to escape and the three do not meet again until after the war.

When Frenz Ferdinend returns to Vienne in the winter of 1918, he finds only his mother unchenged. The Monerchy had ended, his old friends are unable to adjust to post-war Vienne and his wife has left him to become on artist. He feels estranged. With the fomily's fortune lost in the war and no learned trade, he wanders through the streets of Vienne like an orphan. His fatherin-law, Baron Kovocs, is thus able to talk Franz Ferdinand into taking o mortgege out on his mother's home to support Elisobeth's artistic business adventures. The business pertners include Jolenth Szatmery, Elisebeth's instructor and business advisor, and Kurt von Stettenheim, the typical postwar perasite. Even after a second mortgage the business fails to support itself and collepses. With the business lost, Stettenheim quickly leoves town, Jolonth goes to Budapest, and Elisabeth returns to Franz Ferdinand to live with him as his wife and to become the mother of his child. Franz, then facing financial ruin, must turn his mother's home into o boarding house. This venture is olso short lived. After the birth of their son, Franz Joseph Eugen, Elisabeth begins to distance herself from her son and husband and eventually meets up with Jolenth and Stettenheim to become the leading octress of their newly founded film compeny. Within a few months of his wife's deporture to 
Hollywood, Franz Ferdinand's mother dies. He sells the house, sends his son to a friend in Paris and continues his meaningless existence.

As in Radetzkymarsch, Roth brings his picture of the Habsburgs to life in the lifestyles and minds of his characters. Each character is used as a symbol and the fate of each of them runs parallel to that of the dying Monorchy.

Along with his upper closs friends, Franz Ferdinand Trotto lives the decadent life of the pre-wor Viennese citizen. While ofter the war he is unable to adjust and cope with reality. As Carl Joseph had in Radetzkymarsch, Franz Ferdinand typifies Roth's decadent non-hero and is characterized in much the same woy. He no longer odheres to the religious faith of his father's generation. As he explains, he is o religious skeptic because it was the foshion of the time:

Es war keine wirkliche Feindseligkeit gegen die Religion in ihnen, sondern eine Art Hochmut, die Tradition anzuerkennen, in der sie oufgewachsen waren. Zwar wollten sie das Wesentliche ihrer Trodition nicht oufgeben; ober sie -- und ich gehörte zu ihnen --, wir rebellierten gegen die Formen der Tradition, denn wir wußten nicht, deB wahre Form mit dem Wesen identisch ist und doB es Kindisch war, eines von dem andern zu trennen. Es wor kindisch, wie gesogt: ober wir waren damals eben kindisch. (36)

Unlike his father, he lacks feelings of potriotism. The Monarchy and its Emperor seem removed and old. Both hove lost their identity. Fronz Ferdinand and his friends at times perhaps feel the impending doom, but they lack the inner strength to fight. In the doys before the Greot Wor they took pride in so-called decadence. In order to diminish their fears for the future they create an artificial sense of gaiety to fill the viod they feel.

Aus unsern schweren Herzen kamen die leichten Witze, ous unserem Gefühl, daB wir Todgeweihte seien, eine törichte Lust on jeder 
Bestötigung des Lebens: on Ballen, am Heurigen, on Modchen, am Essen, on Spazierfahrten, Tollheiten aller Art, sinnlosen Eskepoden, on selbst-morderischer Ironie, on ungezothmter Kritik, om Prater, am Riesenrad, amkasperltheater, an Maskeroden, am Bollett, on leichtsinnigen Liebesspielen in den verschwiegenen Logen der Hofoper, an Manövern, die man versöumte, und soger noch on jenen Krankheiten, die uns manchmal die Liebe bescherte. (15)

In contrast to his friends, however, Fronz Ferdinend understands the drastic change in people that the wor brought. All that was private suddenly became public and the pest ceesed to exist. Everyone and everything fell victim to world history. Furthermore, Franz Ferdinand could ask himself, "Was hatte dies olles noch für einen Sinn?" (59) He sees that among his frlends, he wos "der einzige. .der schon die Anzeichen des Todes. . .erkennte." (54) And when the death of wor was near, he felt that "ein sinnloser Tod besser sel ols ein sinnloses Leben." (54)

The inability to communicete also plagues Franz Ferdinand's life. He is in love with the nineteen-year-old Elisebeth Kovacs, the doughter of Beron Koyacs, o noblemen from a Hungarian army fomily. But in the above described pre-wor otmosphere there is no room for sentiment. To be in love with 0 women is a weokness and marriege is considered on incurable disease. Feerful of his friends' scorn he keeps his offection hidden and rorely visits Elisobeth. Although often tempted to tell his friends about Elisobeth, he is afroid of becoming their victim and therefore leods, in certain sense, 0 double life.

Roth's stylistic change from third to first person nerrotion exposes further important feotures about Franz Ferdinend's choracter. He seems more conscious of the decoying Monerchy than his friends. As the narrotor of the past he informs us that he did not feel ot ease with his environment. His 
friends' mannerisms bothered him. Their casual liasons with women and the way they regarded their mothers irritated him.

Fronz Ferdinand describes his relationship to his mother os neither true nor sponteneous. From time to time he feels the need to tell her of his love for Elisobeth, but he can not bridge the distance between them. When he leoves to fight in the wor, he concludes "Sie liebte den Sohn ihres Monnes, nicht inr Kind. Sie war eine Frou. Ich wor der Erbe ihres Geliebten; seinen Lenden schicksolhaft entsprossen; ihrem Schoß nur zufallig." (80) But however cold he describes their relotionship he respects her and feels terribly ashamed about the way in which his friends talk obout their mothers. "Sie sprachen von ihren Mūttern beinahe wie von jene "Liesons", die sie sitzten- oder liegenlossen hotten, als wören es ollzu früh gealterte Mătressen, und noch schlimmer, ols wăren die Mütter wenig wŭrdig ihrer Söhne." (24)

In retrospect, fronz Ferdinand blemes his friends for his inability to express his feelings of love for Elisabeth and his mother. They prevented him from obeying the voice of noture and common sense. Although his argument is weok, he, unlike Carl Joseph, recognizes that something ill is in the oir.

Aber es sollte sich jo darauf zeigen, doß diese Sünden, die meine Freunde und ich ouf unsere Höupter luden, gor nicht unsere persönlichen woren, sondern nur die schwochen, noch koum erkennberen Vorzeichen der Kommenden Vernichtung, von der ich bold erzählen werde. (25)

In on attempt to escope the decodence of the metropolis he seeks refuge in the simple, realistic lives of Joseph Branco Trotto and Manes Reisiger. But as Roth shows, even their lives changed with the Great Wor. Manes returns home to find his town annihilated, his wife deed and his son o revolutionary. Joseph Bronco finds he needs a viso to sell his chestnuts in 
the previous Crown Lands. Roth thus conveys the impression that the division of the Empire wos felt not only by the inhebitents of Vienno, but also among the lower classes inhebiting the countryside.

The decay of personal reletionships is further exemplified in Fronz Ferdinend's marrioge. Elisobeth is also charecterized os the decodent Viennese citizen, who seorches for an identity in the cheos of pre- and postwar Austria. She is incepable of love and merries Fronz Ferdinend as custom called for. She lacks genuine affection for her husbond as well as others. On the way to the Hotel Golden Lion, for their one day honeymoon, she prefers a book to Fronz Ferdinend's compeny. Before entering the hotel, Fronz insists on biding Jacques, the Trotto's servant, forewell. Jacques has a stroke and from then on the shadow of death hangs over their honeymoon and marrioge. Elisabeth's reaction to Jecques' death: "Er stirbtl' Sie ließ die ausgebreiten Arme follen und antwortete nur: 'Er ist altl,"' (89) shows her lack of emotion and sensitivity. Franz Ferdinend feels obliged to give the old men his compeny in his final hours ond thereby does not stop Elisobeth from returning to Vienne. Sitting by the dying man's side, Franz Ferdinand concludes, "Ich hatte zwei Tote: die erste wor meine Liebe. Sie begrub ich on der Schwelle der Verbindungstür Zwischen unseren zwei Zimmern." (90)

Upon Frenz Ferdinend's return from the wor Elisobeth attempts to become a wife and mother, but her good intentions last only o short time. After the birth of their son, she finds life os o mother and wife unbeorable and leoves Franz Ferdinand to pursue her egotistical life. Roth allows her no redeeming qualities and emphosizes the decadent femole with the character of Jolanth Szatmary, a lesbion "professor" of art. 
In her appearance, Jolanth is masculine. She is the emancipated woman of the city, who misses no opportunity to further her own gools. Together with Herr von Stettenheim, the third partner of the "commercial art" firm, she uses the Trottes in order to finance her business adventures. She manages to have control of the business, as well as Elisabeth's emotions and can thereby secure the needed funds from Frenz Ferdinand.

Herr von Stettenheim and Baron Kovacs are two more characters along the same line. Both are opportunists, like Jolenth Szatmary. When the war breaks out, Baron Kovacs quickly turns his hat foctory into a supply unit for the militery. As the war grows old his profits lessen and leave him to pursue new ovenues that bring quick money. Although he considers his doughters products of commercial art "junk", he can live with it, so long Franz Ferdinand is poying the bill. When the business eventually faces bankruptcy, he moves on to be an investment counsellor for a newspaper.

Herr von Stettenheim preys on the inflated economy of Austria. With his charm he is able to talk Frau Trotte out of her last cent and live the privileged life of a rich cosmopoliten, that so few could afford. And when the business is dissolved he vanishes to return in the end os opertner in Jolenth's film compony.

Frau von Trotto remains as the only character that upholds the standards and values of pre-war Austrio. Throughout the novel she disploys a strong personality. She does not get involved in Franz Ferdinand's personal affoirs until he shares them with her. She suppresses any emborassing questions to spore herself the shame of being lied to. But once Franz Ferdinand can tell her of his love for Elisabeth she is not afraid to express her dislike for her future doughter-in-law. She understands her son's need to 
marry and gives him her blessing. Since her husband's death, she has lead the secluded life of a widow, but this has not wilted her mind. She has an insight into the character of the people who surround her son and in some ceses cen predict their actions. She dies on the eve of the Civll Wor in 1934 and os Franz Ferdinand states, "Sie starb so, wie sie gelebt hatte: nobel und still." (178)

The last character to be examined is Josef Chojnick1, brother of the crazed Count Wojciech Chojnicki of Badetzkymarsch. Again, this character is Roth's political mouthpiece and the outspoken prophet of the Empire's foll. Chojnicki shares Roth's conviction 2 that:

"In dieser Monarchie. . ist nichts merkwürdig. Ohne unsere Regierungstrottel" (er liebte starke Ausdrücke) "wöre ganz gewiß ouch dem oußerlichen Anschein nach gor nichts merkwürdig. Ich will damit sagen, doß dos sogenonnte Merkwürdige für ÖsterreichUngarn des Selbstyerständliche ist. Ich will zugleich domit ouch sogen, daß nur diesem verrückten Europo der Nationalstoaten und der Notionalismen das Selbstverstondliche sonderbar erscheint. Freilich sind es die Slowenen, die polnischen und ruthenischen Pferdehondler ousder Bacska, die Moslems ous Sorajevo, die Moronibrater aus Moster, die Gott erholte singen. Aber die deutschen Studenten ous Brünn und Eger, die Zahnörzte, Apotheker, Friseurgehilfen, Kunstphotographen ous Linz, Groz, Knittelfeld, die Kröpfe ous den Alpentälern, sie alle singen die Wacht om Rheín. Osterreich wird on dieser Nibelungentreue zugrunde gehn, meine Herren! Dos Wesen Österrelchs ist nicht Zentrum, sondern

2 Evidence of this relotionship between Chojnicki's views and Roth's legitimistic Cotholic ideology is found in Roth's essay "Oreimal Usterreich" written in 1938. He blomes the Prussion influenced Germon Notionalist Party of Austrio for bringing disunity to the Empire's peoples. He felt the resistance and arrogance towards the Slavic minorities caused the once loyal subjects to pursue their independence. As this o major reeson for the Monerchy's disintegration Roth concludes, "Der deutsche Österreicher hat durch die Zertrümmerung der Monarchie seinen Hochmut bereits bitter gebüßt." See Joseph Roth, "Dreimal Üsterreich" Das Neue Tage-Buch 6 (January 20, 1938): 86. 
Peripherie. Österreich ist nicht in den Alpen zu finden, Gemsen gibt es dort und EdelweiB und Enzian, aber kaum eine Ahnung von einem Doppelodler. Die osterreichische Substenz wird genürt und immer wieder oufgefullt von den Kronlöndern." (15-16)

Chojnicki is the conscious patriot, who condems the union of Austrio and Germany and thus represents the few clear-minded Austrians of his time.

The following stylistic observations are also noteworthy. By changing to first person narrator, Roth gives the impression that he strongly identified with his main characters. ${ }^{3}$ Franz Ferdinand's words, "Ich schreibe lediglich zu dem Zweck, um mir selbst klorzuwerden; und ouch pro nomine Dei sozusagen," (98) thus suggests that Roth in this instance is the "Ich" and that Die Kapuzinergruft was his mental therapy - therapy in the sense that writing offered Roth a method for coping with the loss of the Empire.

To intensify the gloomy atmosphere Roth has employed the following leitmotif: "Über den Kelchen, ous denen wir ubermutig tronken, kreutzte der unsichtbare Tod schon seine knochigen Hănde."4 Symbolically and realisticolly deoth hangs over most of the 188 pages of Die Kepuzinergruft. Seven people -- Jacques, Franz's mother and fother, Mones' wife and son, Elisobeth's brother and an ormy deserter -- die physically within the course

3 Otto Forst de Battaglio stotes there is o strong identificotion of Roth with the protogonists of Radetzkymarsch and Die Kopuzinergruft. His orgument is bosed on Roth's outobiogrophical opprooch to his novels and the similarity of Roth's experiences and those of his protogonists. See Otto Forst de Batteglia, "Joseph Roth, Wonderer zwischen drei Welten" Erankfurter Hefte 7 (June, 1952): 444-45. Peter Jonsen also sees o strong existentiol bond between Roth and his work. He writes, "In der Tot wird im Übergong von der Er-Erzöhlung zur IchErzăhlung bei Roth erst gonz offenkündig die existentielle Beteiligung des Dichters on seiner Dichtung." See Hertmut Scheible, Joseph Roth: Mit einem Essay über Gustave Flaubert (Berlin, W. Ger.: W. Kohlhommer, 1971): 162.

4 Roth, Die Kapuzinergruft, 36, 40, 46, 68. 
of the novel. The remaining characters live, but as Franz Ferdinand soys, "Lebendig waren wir und leibhaft vorhenden. Aber Tote waren wir in Wirklichkeit." (178)

Not until ofter Merch 11, 1938 did Roth finish the final chapter of Die Kapuzinergruft, in which he leaves no doubt about the end of the Monorchy and the Trottes. He realized his dream wos over. In the life of Fronz Ferdinand Trotto, Roth offers an emotional look ot his fotherland. He conveys o clear picture of the emptiness of the time. Franz Ferdinand, o man who had no politicel convictions and no identity with the militery, comes from nowhere and goes nowhere. To be an Austrian as he was had no meaning. And when the final blow arrived, he, like Roth, could not cope. Thus I suggest Franz Ferdinand's last question, asked while standing in front of the "Kapuzinergruft": "Wohin soll ich, ich jetzt, ein Trotto?. .." is also Roth's lost question: Wohin soll ich, ich jetzt, ein Roth, ein Österreicher? 


\section{CHAPTER V}

\section{CONCLUSION}

As presented in the enalytical discussion of the preceding pages, it is clear that Badetzkymarsch and Die Kepuzinergruft hove much in common. The following summary will provide a brief overview of the major similiarities and dissimilierites and show that Roth's image of the Empire did not chenge between the two novels; Die Kopuzinergruft was rother o continuation of Rodetzkymarsch.

Both novels contain the themes of lonliness, alienation, disillusionment, incopacity for love, lack of communication, death and the corruptness of social and moral values. Roth had a keen aworeness of the complexity of humen beings. His cheracters ere subject to the forces of humen noture and are thus convincing in their respective roles. The protagonists are weak and drift through life without a purpose. Corl Joseph and Franz Ferdinand belong to the lost generation that was unable to master life and face up to the problems resulting from the fall of the Monarchy. They ore not ot home in the real world and can not find an escepe, as many of their friends do, in the superficial frivolity so common in the Austria of their time. Both fail to secure warm and real relationships with family, friends and the women. They yearn to be close to their peosent forefothers and make honorable attepts to achieve that gool. In fact at times their desire is so strong that they do not hesitote to sacrifice their stotus. As decodent non- 
heros they not only contribute to, but ore pessively subjected to the foll of the Monarchy. In sum, Carl Joseph and Franz Ferdinand are self-reflective, melancholic cheracters, who shed light on Roth's own generation.

The protogonists ore surrounded by a number of similiar cheracters. The decodent officers of Corl Joseph regiment disploy the some corelessness as Franz Ferdinand's "Koffeehaus" companions. The female characters correspondingly lack the ability to bring love, warmth and coring into the life of the novels. One more similiarity can be pointed out in the respective Chojnickis. They ore the outspoken, open-minded prophets of doom, who represent the minority, which was aware of the political situation and dored to voice its opinion.

The following differences occur, I feel, as the natural consequences of the political and sociological changes that came about ofter the First World War. Roth's choice to keep the same family line and parallel persanalities enables the reader to be familiar with the characters. This familiarization focilitates perception of the degree of change that occured in Austrian society from the point where Radetzkymarsch left off to 1938. I suggest it is not the personal lives of Carl Joseph and Franz Ferdinand that are important, but rather the overall life in the Empire of which they ore victims of and which they represent.

Although the protagonists are similiar in many ways, Roth has given Franz Ferdinand one quality that sets him apart from Corl Joseph. Franz Ferdinand senses the ills of his society. He feels war on his doorstep and knows it is real. In contrast to Corl Joseph, Franz Ferdinand can no longer see the world through rose-colored glasses, he can not remain blind and can see the couses behind the Empires dissolution. Any hope that Corl moy have 
had is diminished by the time Franz steps on the stoge. When Fronz Joseph 1 dies and the war is over Franz Ferdinend must find his way in a world Carl Joseph could never have imagined. It is in this unbearable world, of which he does not want to be a part, that the truth of what has happened and will happen reveals itself to him:

Soh ich mich doch seit langem schon, seit der Heimkehr aus dem Krieg, als einen zu Unrecht Lebenden on! Hatte ich mich doch längst schon daran gewöhnt, alle Ereignisse, die von den Zeitungen "historische" genannt werden, mit dem gerechten Blick eines nicht mehr zu dieser Welt Gehörenden zu betrachten! Ich war lange schon ein vom Tode ouf unbeschränkte Zeit Beurlaubtert Und er, der Tod, konnte jede Sekunde meinen Urlaub unterbrechen. Wos gingen mich noch die Dinge dieser Welt on? ... I Ich war ausgeschaltet; ousgeschaltet war ich. Ausgeschaltet unter den Lebendigen bedeutet so etwos Ähnliches wie: exterritorial. Ein Exterritorialer war ich eben unter den Lebenden. 1

The replacement of Joseph and Franz Trotta, the father figures and symbols of militery and bureaucratic power, by Baron Kovacs, Herr von Stettenheim and Jolanth Szatmary indicates the decline of the social and moral values. The powers of the odministrative and military institutions, which once had been the pillars of the Austro-Hungarian Empire, became exploited by the ruthless opportunists of the Austrian Republic of Die Kapuzinergruft.

The female image in Die Kopuzinergruft is o further example of sociological change and allows for contrast between the two novels. As stated earlier, the female characters lack wormth and love in both novels. However, the mother figures hove vonished in Die Kepuzinergruft and ore replaced by the emancipated urben woman, who has little need for a man to keep her young and comforted.

1 Roth, Die Kopuzinergruft, 183-4. 
Before I conclude I would like to point out o peculiar feoture. In my research I heve found an obundence of secondery literature that deals with Radetzkymarsch. There ore numerous critical works, eech different in its conclusions, that investigate Roth's attitude towards the lost Empire and the socio-political and moral volües of the Austro-Hungarion Empire he presented in the novel. For example, Claudio Mogris concludes that the novel does not idealize the post, but gives o realistic account of the Trotto fomily, whose fote is that of the Empire. He stotes, "In der Tot enthalt dieser Romen den ganzen, im Ton unoufhaltsamen Niedergangs enthaltenen Geist einer Zeit. 2 On the other end of the spectrum of interpretations stends Georg Lukfocs, who points out that Roth folled to give an all-encompessing picture of the decline of the Empire. As he states, "Roth bringt die Geschichte des Zusommenbruchs des Reiches nicht voll und ganz. 3 However, as porodox as it may seem, oll interpretotions I hove read conclude that the novel stands as Roth's finest literory ochievement.

The peculiority arises, when one attempts to find the same type of secondery literature for Die Kapuzinergruft. There is basically none. Although Hertmut Scheible has dedicated o whole chopter to the discussion of this novel, most critics, if they at all mention it, devote o mere paragroph. And the sod foct is that in this porogroph, which is for from a compliment,

2 Cloudio Mogris, Der Hebsburgische Mythos in der Q̈sterreichischen Literotur (Solzburg, Aus.: Otto Müller, 1966): 263.

3 Georg Lukócs, "Radetzkymarsch," in Fritz Hackert, Kulturpessimismus und Erzählform: Studien zu Joseph Roth Leben und Werk (Bern, Switz.: Herbert Long, 1968): 151. 
Die Kopuzinergruft is usually described os the inferior and ideologically weaker sequel to Rodetzkymarsch.

A possible reason for this inequality may stem from the fact that Die Kopuzinergruft was published a year before Roth's death. Anyone familiar with his life would know he was a heavy drinker at that time. Knowledge of his alcoholism may lead many to look with bias upon the novel. Stefon Zweig, a close friend of Roth's for many years, however, was convinced that alcohol did not impoir the quality of Roth's writing. In a letter to his sister, Zweig writes, "Es ist eigentlich ein Wunder, wie unbeschädigt sein Gehirn geblieben ist. Er ist genau der große Künstler wie früher. ..."4

In my close examination of both novels I must say I have come to agree with Stefan Zweig and disagree with those who see Die Kapuzinergruft as only the unimportont sequel. Die Kopuzinergruft is not only the continuation of Rodetzkymarsch, but also its worthy conclusion. If one wants a clear picture of Roth's evolution of thought on the subject that touched him most, one should pick these two novels from the bookshelf as though they were bound os one. Together they cover o span of seventy-nine years and offer o detailed literary account of pre- and post-wor Austrio. In effect they represent Roth's effort to deol with the some subject. Die Kopuzinergruft thus of fered Roth the chance to tell what he left untold in Redetzkumarsch.

The atrophy of the Empire that begins in Radetzkymersch is radically continued in Die Kepuzinergruft, so that by the end of the novel one is convinced that no other solution would have been possible. The pride and glory of the Empire that the title "Rodetzkymarsch" symbolizes, hints at

4 Stef on Zweig and Friederike Zweig, Briefwechsel 1912-1942 (Bern, Switz.: Herbert Long, 1951): 318. 
Roth's hope for the restorotion of Habsburg power. However, by 1938 what other title could heve been more appropriate than "Die Kopuzinergruft."? The Empire was buried and Roth had come to terms with this.

These novels illustrate Roth's reactions to the First World Wor and its aftermath. The social and political problems of his time are mirrored in these two creative works and show that the politicel and morel upheavals of the war had just as much of an impact on the outhor as on such better known writers as Schnitzler, Musil, Zweig and Krous. The emptiness and suffering Roth struggled with throughout his life seem to have been the mojor impetus behind his creativity. He recognized the disease which infected the society of his time and clearly conveys his understanding on the pages of this "novel" in two perts. For the Empire he loved and lost, he wrote Radetzkymarsch o sogo, and Die Kapuzinergruft, an epitoph. 


\section{A SELECTED BIBLIOGRAPHY}

Böll, Heinrich. "Ein Denkmal für Joseph Roth." Erzöhlungen, Hörspiele,

Aufsätze. Köln, W. Ger.: Kiepenheuer, 1961. 361-64.

---. "Die Trauer, die recht behielt: Leben und Werk yon Joseph Roth."

Deutsche Rundschau 83 (1957): 274-78.

Bōning, Hansjürgen. Joseph Roths 'Rodetzkymarsch': Themotik, Struktur,

Sprache. München, W. Ger. Wilhelm Fink, 1968.

Boveri, Mergret. "Joseph Roth und die Frenkfurter Zeitung." Merkur 25

(1971): 786-98.

Bronsen, Dovid. "Die Ambitionen des jungen Joseph Roth." Text und Kritik Sondertbend (1974): 32-39.

---. The Jew in Search of a Fatherland: The Relotionship of Joseph Roth to the Hobsburg Monerchy." Germanic Review 54 (1979): 54-61.

---. Joseph Roth: Eine Biographie. Kōln, W. Ger.: Kiepenheuer, 1974.

---. "Joseph Roths Kriegsdienst 1916-18." Schweizer Monatshefte 49 (1969/70): 569-81.

---. "Phantosie und Wirklichkeit: Geburtsort und Voterschoft im Leben Joseph Roths." Neue Rundschou 79 (1968): 494-505.

---. "Die verlorene Heimat: Zur Klărung eines fingierten Briefes und eines nie veröffentlichen Romans yon Joseph Roth." Essays on European Literoture: In Honor of Liselotte Dieckmann. Ed. Peter Uwe Hohendahl, Herbert Lindenberger, and Egon Schwarz. St. Louis:

Washington UP, 1972. 101-12. 
Dittberner, Dovid. "Uber Joseph Roth." Text und Kritlk Sonderband (1974): 10-31.

Dollenmayer, David. "History and Fiction: The Kaiser in Joseph Roth's 'Radetzkymarsch."' Modern Language Studies 16 (1986): 302-10.

Eckermann, Johann Peter. Gespräche mit Goethe in den letzten Jahren.

Berlin, W. Ger: Aufbou Verlog, 1956.

Forst De Battaglia, Otto. "Joseph Roth, Wanderer zwischen drei Welten."

Frankfurter Hefte 7 (June, 1952): 441-45.

Hockert, Fritz. "Joseph Roth: Zur Biogrophie." Deutsche

Vierteljohrsschrift für Literaturwissenschaft und

Geistesgeschichte 43 (1969): 161-86.

---. Kulturpessimismus und Erzöhlform: Studien zu Joseph Roths Leben und Werk. Europåische Hochschulschriften 5. Bem, Switz.: Herbert Lang, 1968.

Halldén, Eleonoro. "Das Phänomen Österreich im Leben und Werk Jopseph Roths." Literatur und Kritik 104 (1976): 226-38.

Hoffmeister, Werner G. "Eine ganz bestimmte Art von Sympathie":

Erzählhaltung und Gedankenschilderung in Joseph Roths

'Radetzkymarsch."' Seminar: A Journal of Germanic Studies 9 (1973): 50-65.

Jehmüller, Wolfgang. "Zum Problem des zweifachen Zeugnisses bei Joseph

Roth." Text und Kritik Sonderband (1974): 67-75.

Kesten, Hermann, ed. Joseph Roth: Briefe 1911-1939. Kőln, W. Ger.: Kiepenheuer, 1970.

---, ed. Joseph Roth: Werke in drei Bănden. Köln, W. Ger.: Kiepenheuer, 1956. 
---. "Der Schriftsteller Joseph Roth." Text und Kritik Sonderbend (1974): 7-9.

Krispyn, Egbert. "Joseph Roth and the Art of Adaptation." Protest--Form-Tradition: Esssays on German Exile Literature. Ed. Joseph P. Strelka, Robert F. Bell, and Eugene Dobson. Alabamo: U of Alabama P, 1979. 97-111.

Kunitz, Stanley and Howard Hoycroft, eds. Iwentieth Century Authors.

New York: H.W. Wilson, 1942.

Magris, Claudio. Der Hobsburgische Mythos in der Usterreichischen

Literotur. Solzburg, Aus.: Otto Müller, 1966.

---. "Joseph Roth: Der Aufbruch ouf der Suche nach dem Bekennten."

Literatur und Kritik 75 (1973): 277-91.

Moier, Wolfgang. Typische Formen der Geschehnisstruktur in Joseph Roths

'Rodetzkymarsch."' Archiy für das Studium der neueren Sprachen und Literaturen 214(1977): 71-79.

Manger, Philip. "The Redetzky Morch'; Joseph Roth and the Hebsburg Myth." The Viennese Enlightenment. Ed. Mark Froncis. New York: St. Mortin's, 1985. 40-63.

Marcuse, Ludwig. "Die neue Unsachlichkeit." Die Zeit 20.36 (1965): 11. Musil, Robert. Mann ohne Eigenscheften. Homburg, W. Ger.: Rowohlt, 1965. Ringel Fred J. "Morch in Reverse." The Soturday Review of Literature 10 (1933): 217-18.

Rosenfeld, Sidney. "Grenze und Untergong in Joseph Roths

'Redetzkymarsch."' Modern Austrian Literature 2.3 (1969): 12-16.

---. "Joseph Roth and Austrio: A Seorch for Identity." Leo Boeck Institute Year Book 31 (1986): 455-65. 
Roth, Joseph. "Dreimal Üsterreich." Das Neue Tage-Buch 6 (January 6, 1938): 84-88.

---. Die Kopuzinergruft. Köln, W. Ger: Kiepenheuer, 1972.

---. Rodetzkymarsch. Köln, W. Ger.: Kiepenheuer, 1950.

Senger, Curt. The Figure of the Non-Hero in the Austrian Novels of Joseph Roth." Modern Austrien Literature 2.4 (1969): 35-37.

Santer, Eric. "Geschlossenheit, Geschichte und Welt in Joseph Roths

'Radetzkymarsch." Rocky Mountain Review of Language and Literature 36 (1982): 45-49.

Sasse, Sonja. "Der Prophet als Außenseiter." Text und Kritik Sonderband (1974): $76-89$.

Scheible, Hartmut. Joseph Roth: Mit einem Essay über Gustave Flaubert. Stuttgart, W. Ger.: W. Kohlhammer, 1971.

---. "Joseph Roths Flucht ous der Geschichte." Iext und Kritik Sonderband (1974): 56-66.

Schonauer, Fronz. "Ober den Dichter Joseph Roth." Akzente 4 (1957): 28186.

Siepmann, Thomas. "Joseph Roths 'Radetzkmarsch' in der Schule. Der Deutschunterricht 36 (1984): 83-94.

Steiner, Carl. "Frankreichbild und Katholizismus bei Joseph Roth." The Germen Quarterly 46 (1973): 12-21.

Strelka, Joseph. Auf der Suche nach dem verlorenen Selbst: Zu deutscher Erzählorose des 20. Jehrhunderts. Bern, Switz.: Herbert Lang, 1977. Trommler, Franz. Romen und Wirklichkeit: Eine Ortsbestimmung am Beispiel von Musil, Broch, Roth, Doderer und Gütersloh. Stuttgart, W. Ger:: W. Kohlhemmer, 1966. 
Weiss, Welter. "Österreichische Literatur -- eine Gefangene des habsburgischen Mythos?" Deutsche Vierteljahrsschrift für Literaturwissenschaft und Geitesgeschichte 43 (1969): 333-45.

Williams, C.E. The Broken Eagle: The Politics of Austrien Literoture from

Empire to Anschluss. New York: Bornes, 1974.

Zweig, Frederike. "Joseph Roth and the Zweigs." Books Abroad 18 (1944): 5-8.

Zweig, Stef an and Friederike Zweig. Briefwechsel 1912-1942. Bern, Switz: Herbert Lang, 1951. 